\title{
Sistem Informasi Pemasaran dan Penjualan Hasil Tenun Ulos Desa Lumban Suhi-Suhi
}

\author{
Ropita Hotrezkina Malau ${ }^{1}$, Tonni Limbong ${ }^{2}$ \\ ${ }^{1,2}$ Universitas Katolik Santo Thomas Medan, Jl. Setiabudi No. 479 F Tanjungsari, Medan, Indonesia
}

\section{ARTICLE INFORMATION}

Received: September, 20, 2020

Revised: September, 29, 2020

Available online: Oktober,31 2020

\section{KEYWORDS}

Five words maximum, comma separated

SISTEM INFORMASI, WEBSITE, PEMASARAN

DAN PENJUALAN, LUMBAN SUHI-SUHI,

ULOS

Phone: +62 822-7576-6021

E-mail: tonni.budidarma@gmail.com

\section{A B $\mathbf{S}$ T $\mathbf{R}$ A $\mathbf{K}$}

\begin{abstract}
Dengan adanya teknologi informasi dan komunikasi dapat memudahkan untuk belajar dan mendapatkan informasi yang dibutuhkan dari mana saja, kapan saja dan dari siapa saja. Salah satu wadah yang dirasa paling berperan dalam dunia teknologi informasi dan komunikasi di Indonesia saat ini adalah internet. Penggunaan internet dalam dunia bisnis berfungsi sebagai alat untuk alplikasi strategi bisnis online, seperti: pemasaran, penjualan, dan pelayanan pelanggan. Hal ini dibuktikan dengan banyaknya perusahaan besar yang menggunakan atau memanfaatkannya untuk perkembangan bisnisnya misalnya toko online. Dengan dibangunnya sistem informasi pemasaran dan penjualan hasil Ulos Desa Lumban Suhi-Suhi, dapat memberikan salah satu alternatif dan kemudahan dalam menjalankan pengembangan usaha Desa Tenun Ulos Desa Lumban Suhi-Suhi. Disamping itu penjualan dengan website diharapkan pengolahan data pembelian menjadi lebih terformat rapi.
\end{abstract}

\section{PENDAHULUAN}

Ulos dalam pengertian umum adalah kain tenun tradisional batak yang terdiri dari berbagai jenis, corak atau motif, fungsi serta ukuran.Ulos merupakan hasil tenun yang umumnya ditenun oleh wanita Batak. Ulos ini digunakan dalam setiap upacara adat pada masyarakat Batak khususnya masyarakat Batak Toba. Proses pemberian Ulos (mangulosi) pada masyarakat Batak Toba ini akan dilakukan sesuai dengan sistem Dalihan Natolu yang mempunyai peranan yang sangat penting dalam setiap upacara adat baik didalam upacara adat Perkawinan, upacara adat Kematian, Tujuh Bulanan, Memasuki Rumah Baru. Jenis-jenis Ulos yang paling sering digunakan dalam setiap upacara adat seperti dalam (a) upacara Pernikahan adalah sebagai berikut: Panssamot, Ulos Holong, Ulos Sadum, (b) Ulos dalam upacara Kematian yaitu Ulos Saput dan Ulos Tujung, Ulos Ragihotang, Ulos Sampetua dan Ulos Holong (c) Ulos yang digunakan dalam upacara Memasuki Rumah Baru yaitu: Ulos Sampetua (d) Ulos yang digunakan dalam upacara adat Tujuh Bulanan yaitu Ulos Bintang Maratur dan Ulos Mulagabe [1], [2].

Penjualan adalah kegiatan yang dilakukan oleh penjual dalam menjual barang atau jasa dengan harapan dapat memperoleh laba dari adanya suatu trasaksi-transaksi tersebut [3], [4]. Seperti dikutip dari Wikipedia, pengertian Penjualan (sale) adalah aktivitas atau bisnis menjual produk atau jasa. Dalam proses penjualan, penjual atau penyedia barang dan jasa memberikan kepemilikan suatu komoditas kepada pembeli untuk suatu harga tertentu. Penjualan dapat dilakukan melalui berbagai metode, seperti penjualan langsung, dan melalui agen penjualan. Bagaimana menciptakan hubungan jangka panjang dengan pelanggan melalui produk atau jasa perusahaan. Dalam hal ini penjualan berarti sebuah taktik yang dapat mengintegrasikan perusahaan, pelanggan, dan relasi antara keduanya [5], [6].

Pemasaran adalah suatu sistem keseluruhan dari kegiatan-kegiatan bisnis yang ditujukan untuk merencanakan, menentukan harga, mempromosikan dan mendistribusikan barang atau jasa yang memuaskan kebutuhan baik kepada pembeli yang ada maupun pembeli potensial [7]. Sistem informasi adalah suatu sistem didalam suatu organisasi yang mempertemukan kebutuhan pengolahan transaksi harian, mendukung operasi, bersifat manajerial dan kegiatan strategi dari suatu organisasi, dan menyediakan pihak luar tertentu dengan laporan - laporan yang diperlukan [8].

Jadi dapat disimpulkan bahwa sistem informasi adalah suatu alat yang membantu dalam menyediakan informasi bagi penerimanya dan untuk membantu dalam pengambilan keputusan bagi manajemen didalam operasi perusahaan sehari-hari dan informasi yang layak untuk pihak luar perusahaan[3], [9], [10]. Sistem informasi penjualan merupakan suatu sistem yang terdiri dari kumpulan orang, peralatan dan prosedur yang memadukan antara pekerjaan mesin (komputer) dan manusia yang menyajikan keakuratan informasi bagi para pemakai dalam membuat keputusan untuk memecahkan masalah didalam perusahaan. (Kolter (1999: 100)

Di kabupaten Samosir banyak Pengrajin Ulos yang menghasilkan Ulos dengan motif dan corak yang cantik dan beragam. Namun cara pembeliannya masih manual dan bisa dibilang sangat biasa karena Ulos tersebut hanya dipajangkan didepan rumah, sehingga 
penjualannya tidak terlalu banyak dan tidak bisa menarik konsumen secara luas. Di desa Lumban Suhi Suhi Toruan belum mempunyai sistem informasi yang mendukung dalam proses penjualan Ulos, serta dalam memasarkan dan memperkenalkan Ulos ke masyarakat luas belum mempunyai media promosi yang dapat mencakup pasar luas [11].

Dengan adanya masalah yang dihadapi oleh Desa Lumban Suhi Suhi Toruan tersebut, maka dibutuhkan teknologi informasi berupa sistem informasi yang dapat membantu penyampaian informasi produk dan harga secara detail kepada konsumen. Selain itu melalui sistem informasi akan dapat mengakses informasi yang dibutuhkan kapan saja dan dimana saja. Suatu sistem informasi akan menjelaskan bagaimana proses penjualan Ulos dilakukan sehingga dapat ditampilkan waktu pemesanan dan waktu yang dibutuhkan untuk mengirimkan pesanan hingga sampai kepada pelanggan yang memesannya. Tidak hanya itu, dengan adanya sistem informasi, penjualan Ulos akan dapat memperluas jangkauan pemasaran..

\section{METODE PENELITIAN}

Adapun metodologi penelitian skripsi adalah sebagai berikut [12], [13]:

a. Observasi

Teknik pengumpulan data melalui pengamatan yang dilakukan terhadap objek (Ulos) yang diteliti dengan menggunakan pencatatan secara sistematis terhadap informasi Ulos yang ada di Desa Lumban Shi-Suhi. Catatan yang diperoleh dari pengamatan ini adalah berupa nama Ulos, jenis Ulos, harga Ulos, keterangan hingga ukuran Ulos.

b. Interview / Wawancara

Metode pengumpulan data yang dilakukan dengan cara tanya jawab secara langsung kepada pengrajin atau penenun Ulos tentang data-data yang berhubungan dengan Ulos itu sendiri.

c. Studi Pustaka

Studi Pustaka yaitu penelitian yang dilakukan dengan cara membaca dan mempelajari buku-buku yang berhubungan dengan masalah yang akan diteliti sebagai tinjauan pustaka. Dalam penelitian ini, referensi yang digunakan berupa buku serta penelusuran melalui internet.

d. Studi lapangan

Studi lapangan adalah pengumpulan data secara langsung ke lokasi menggunakan teknik wawancara, karena teknik wawancara adalah teknik yang paling sosiologis yang bisa penulis gunakan karena bentuknya yang berasal dari interaksi antara peneliti dan responden dan juga merupakan cara yang paling baik.

e. Referensi Internet

Mencari tutorial, mengunduh, mengumpulkan data yang berhubungan dengan perancangan sistem informasi penjualan dan pemasaran hasil tenun Ulos kabupaten Samosir dan referensi-referensi yang berkaitan.

\section{HASIL DAN PEMBAHASAN}

Implementasi merupakan suatu cara atau langkah yang digunakan untuk memperkenalkan bagaimana cara mengoperasikan sistem yang telah dibangun. Dimana dengan adanya implementasi, maka penguna sistem akan lebih mudah memahami bagaimana cara menjalankan sistem tersebut. Pada tahap ini akan dijelaskan apa saja yang menjadi antar muka atau interface yang dapat diakses oleh pelanggan pada sistem yang akan dibangun. Adapun halamanyang dapat diakses oleh pelanggan dijelaskan sebagai berikut: 1. Tampilan Halaman Utama Sistem

Halaman ini merupakan tampilan yang pertama kali muncul saat pengunjung membuka aplikasi yang akan dibangun. Dengan halaman utama, maka setiap pengunjung dapat mengakses halaman-halaman lain. Bentuk dari Tampilan halaman utama dapat dilihat seperti pada Gambar 1 berikut.

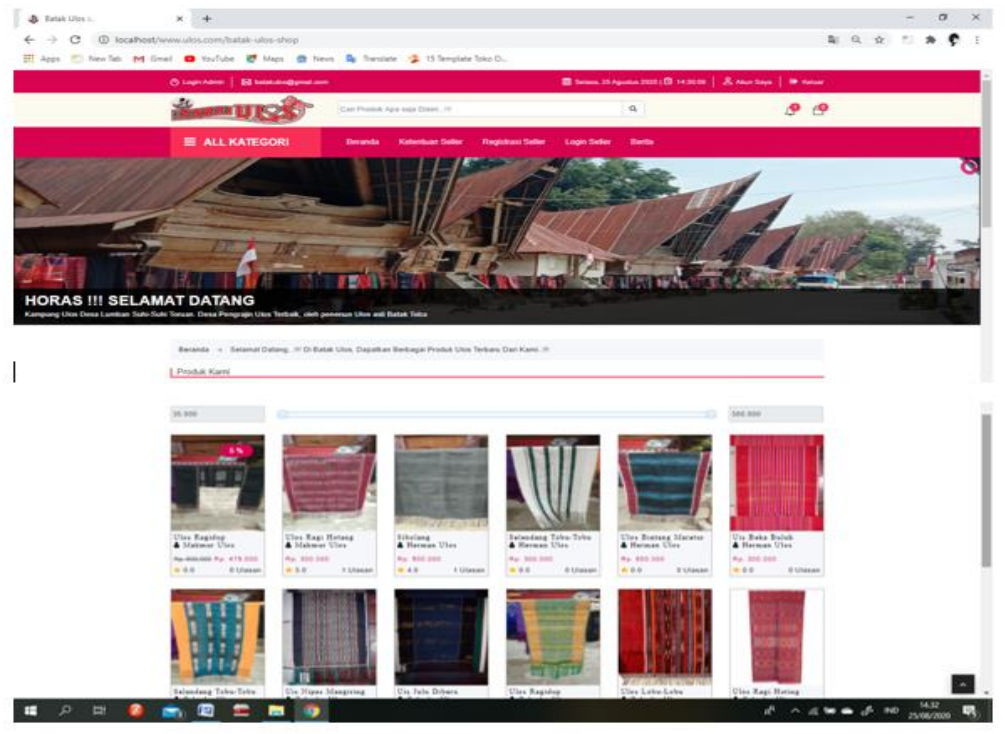


2. Tampilan Halaman Detail Produk

Gambar 1. Tampilan Halaman Utama Sistem

Pada halaman ini akan ditampilkan informasi detail Produk yang dipilih oleh pengunjung. Adapun bentuk halaman detail paket dapat dilihat seperti pada Gambar 2 berikut.

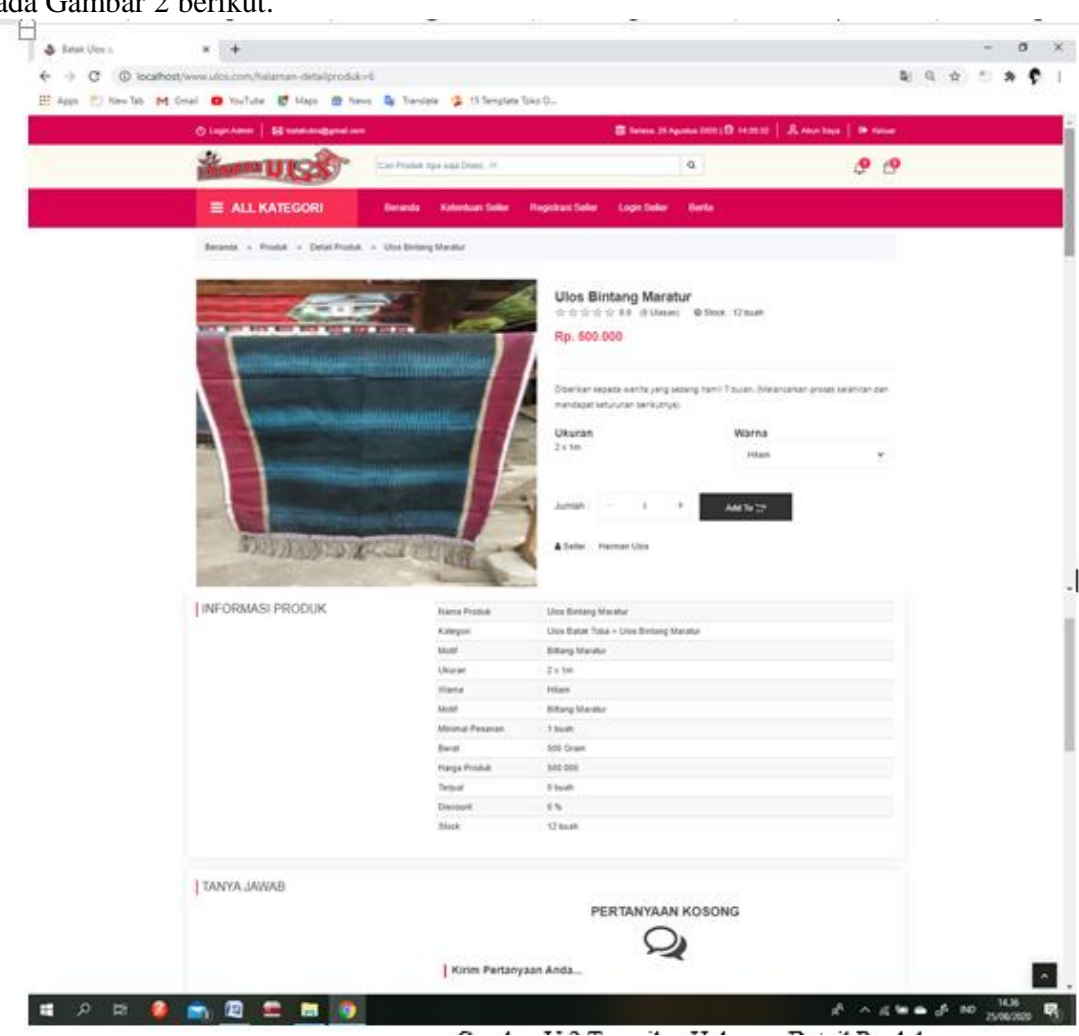

Gambar.2. Tampilan Halaman Detail Produk

3. Tampilan Halaman Feedback Pelanggan

Pada halaman ini akan ditampilkan informasi dan penilaian yang diberikan oleh pelanggan yang melakukan pemesanan Ulos. Adapun bentuk halaman Feedback pelanggan dapat dilihat seperti pada Gambar 3 berikut.

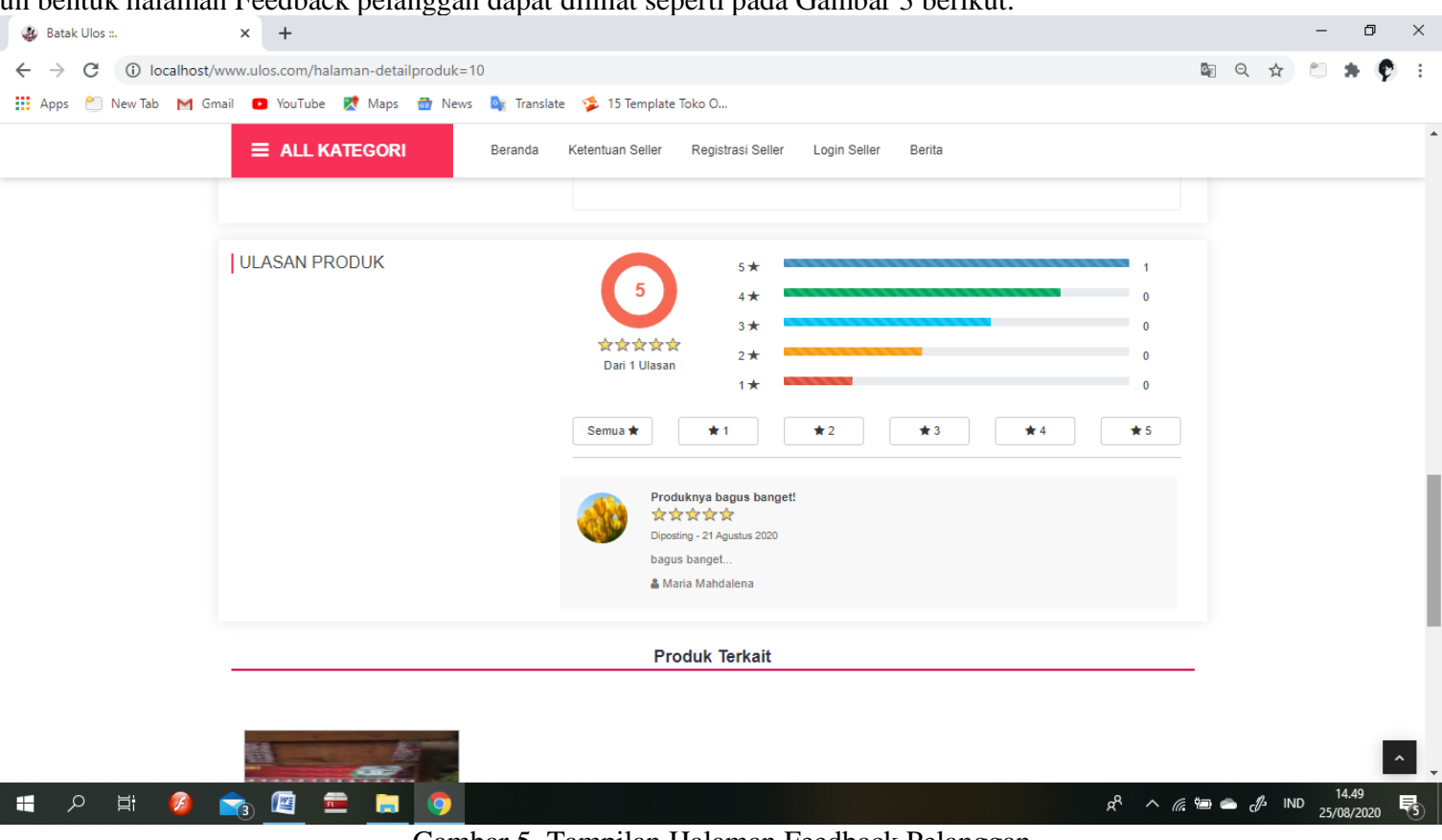

Gambar 5. Tampilan Halaman Feedback Pelanggan

4. Tampilan Halaman Registrasi Pelanggan

Pada halaman ini akan ditampilkan informasi tentang cara melakukan registrasi atau pendaftaran dengan mengisi data-data yang diminta. Adapun bentuk halaman registrasi pelanggan dapat dilihat seperti pada Gambar 6 berikut. 


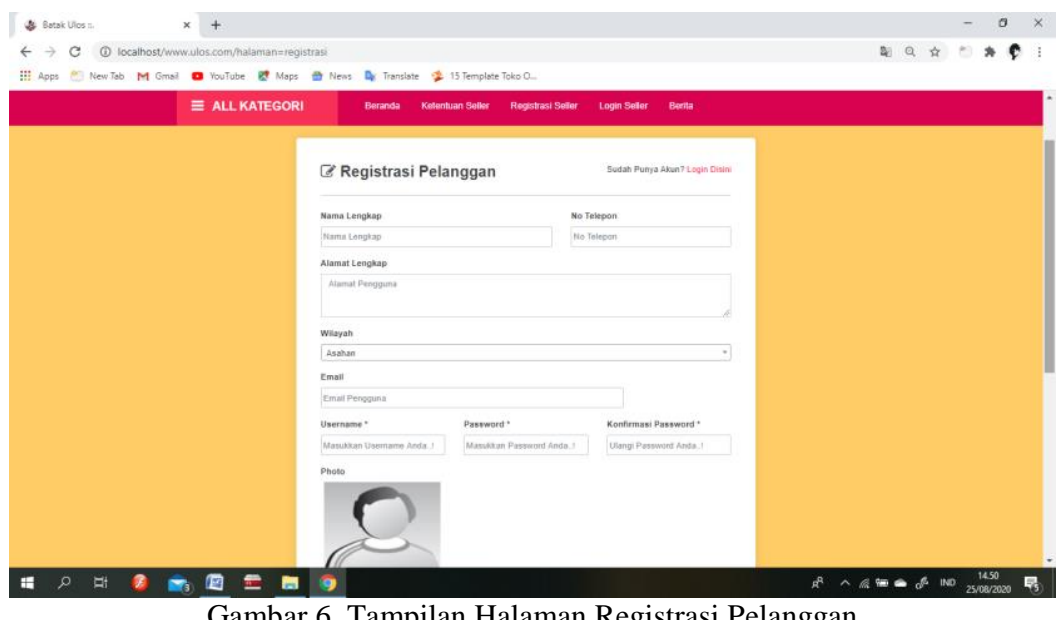

Gambar 6. Tampilan Halaman Registrasi Pelanggan

5. Tampilan Halaman Utama Pelanggan

Halaman utama pelanggan berfungsi untuk menampilkan daftar pesanan, notifikasi dan keranjang belanja. Tampilan halaman registrasi pelanggan dapat dilihat seperti pada Gambar 7 berikut.

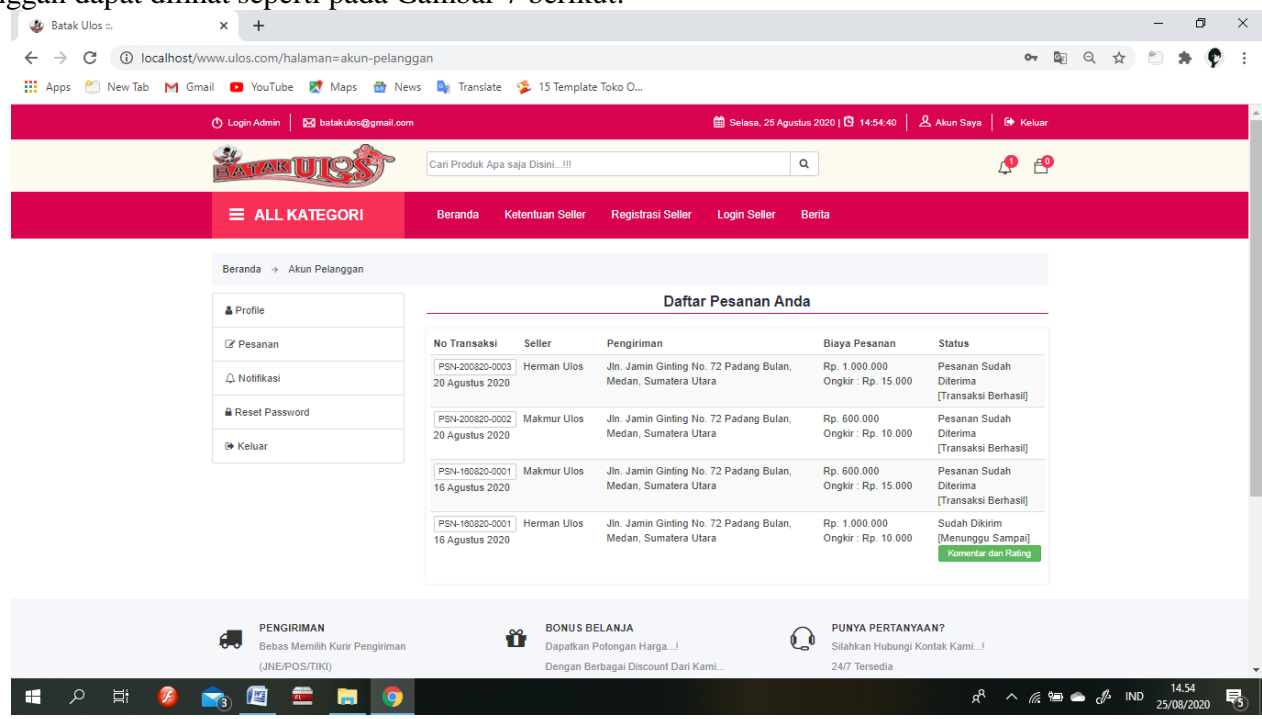

Gambar 7. Tampilan Halaman Utama Pelanggan

6. Tampilan Halaman Pesanan Pelanggan

Tampilan halaman pesanan pelanggan akan memberikan informasi tentang daftar produk yang dipesan. Bentuk Tampilan halaman pesanan pelanggan dapat dilihat seperti pada Gambar 8 berikut.

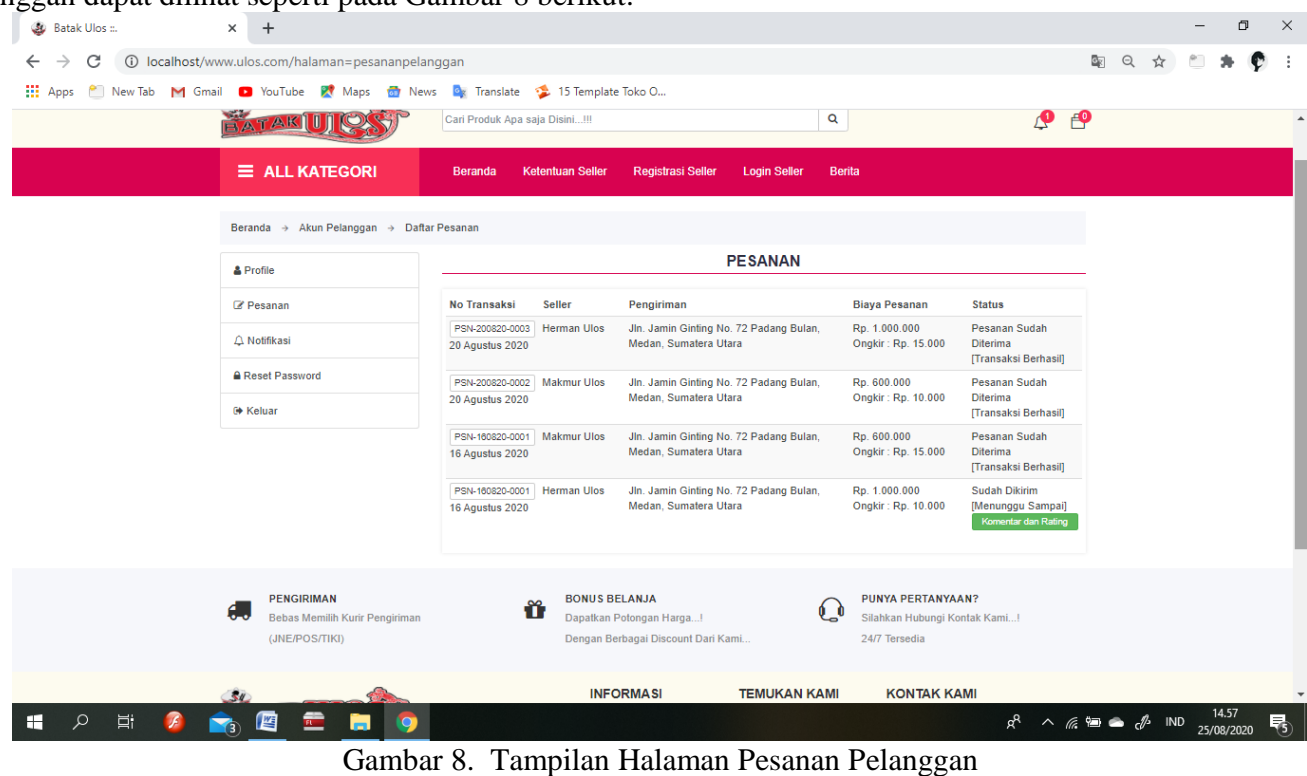

Sistem Informasi Pemasaran dan Penjualan Hasil Tenun Ulos Desa Lumban Suhi-Suhi . 
7. Tampilan Halaman Pemesanan Produk

Tampilan Halaman pemesanan produk akan memberikan informasi tentang semua pesanan yang akan dilakukan oleh pelanggan. Bentuk Tampilan halaman pemesanan produk dapat dilihat seperti pada Gambar 9 berikut.

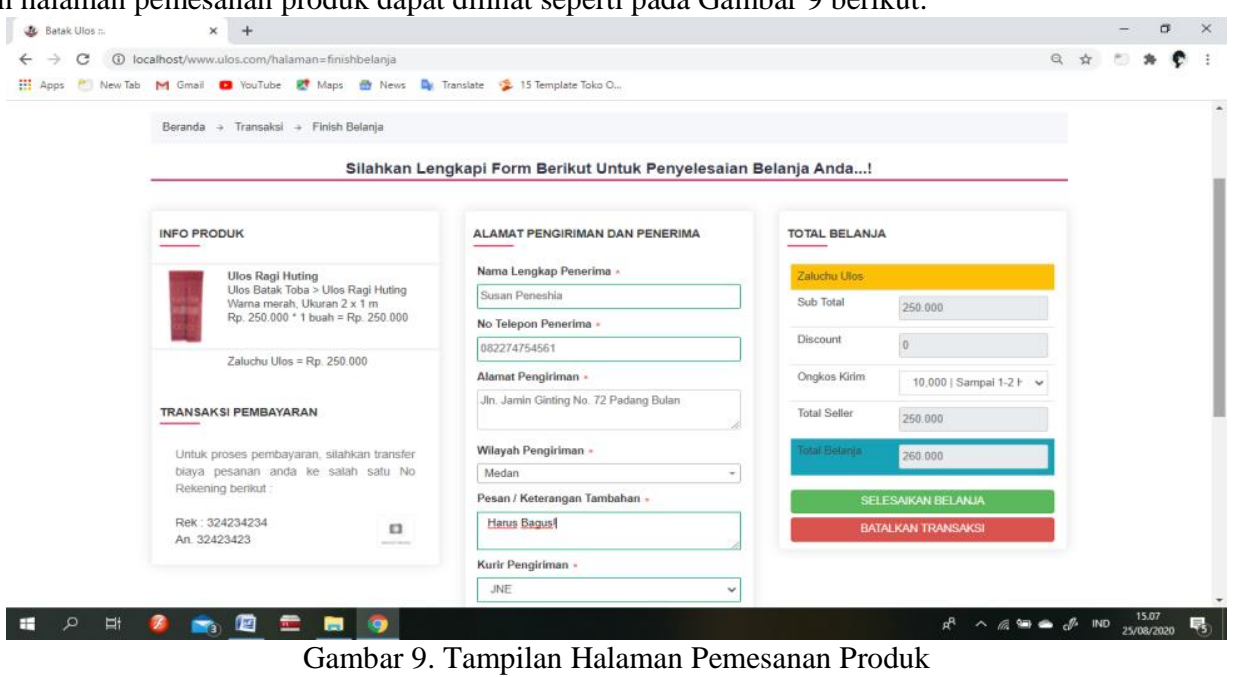

8. Tampilan Login Seller

Pada halaman ini akan ditampilkan halaman login seller. Adapun bentuk tampilan login seller dapat dilihat seperti pada Gambar 10 berikut.

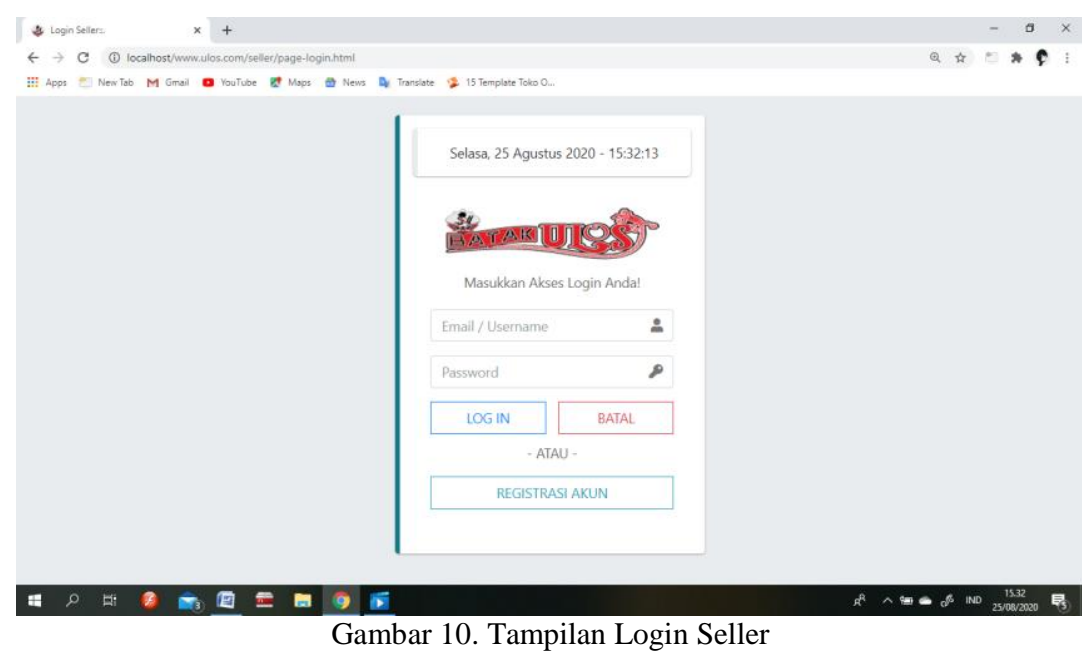

9. Tampilan Halaman Utama Seller

Pada halaman ini akan menampilkan informasi, produk, profil dll. Pada halaman ini seller bebas mengubah data-data yang diinginkan. Adapun bentuk halaman utama seller dapat dilihat seperti pada Gambar 11 berikut.

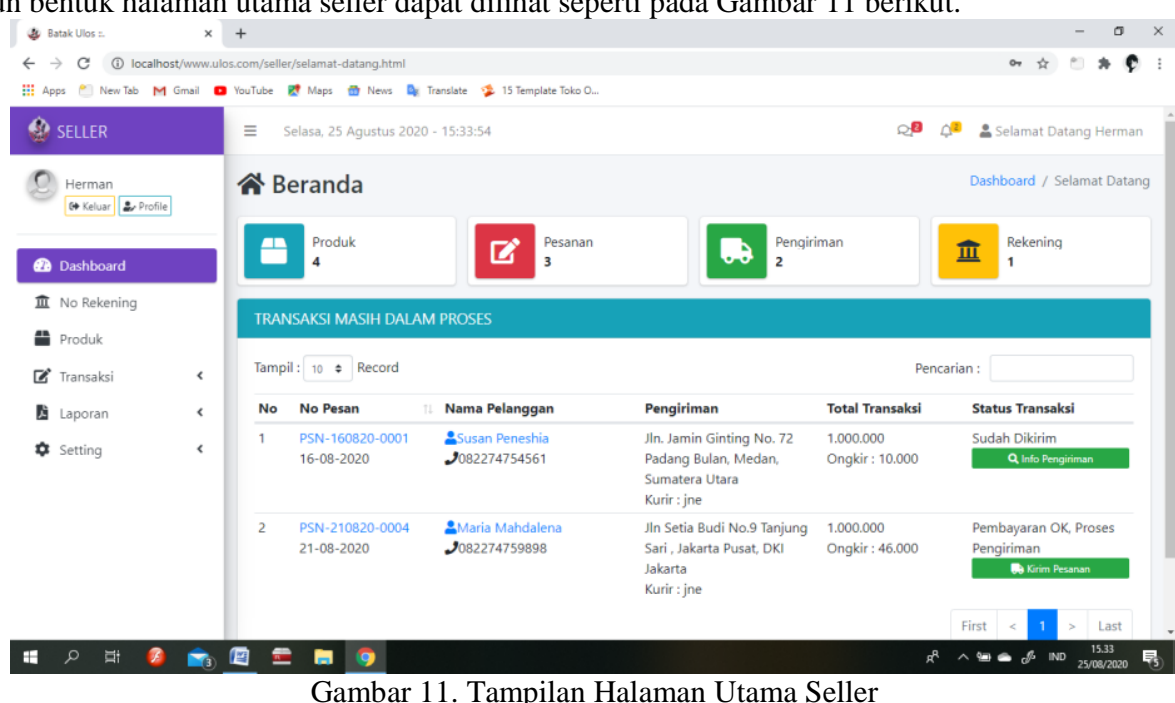

Gambar 11. Tampilan Halaman Utama Seller

Sistem Informasi Pemasaran dan Penjualan Hasil Tenun Ulos Desa Lumban Suhi-Suhi . 
10. Tampilan Halaman Daftar Produk

Pada halaman ini akan ditampilkan daftar produk ulos yang akan dijual. Adapun bentuk halaman daftar produk dapat dilihat seperti pada Gambar 12 berikut.

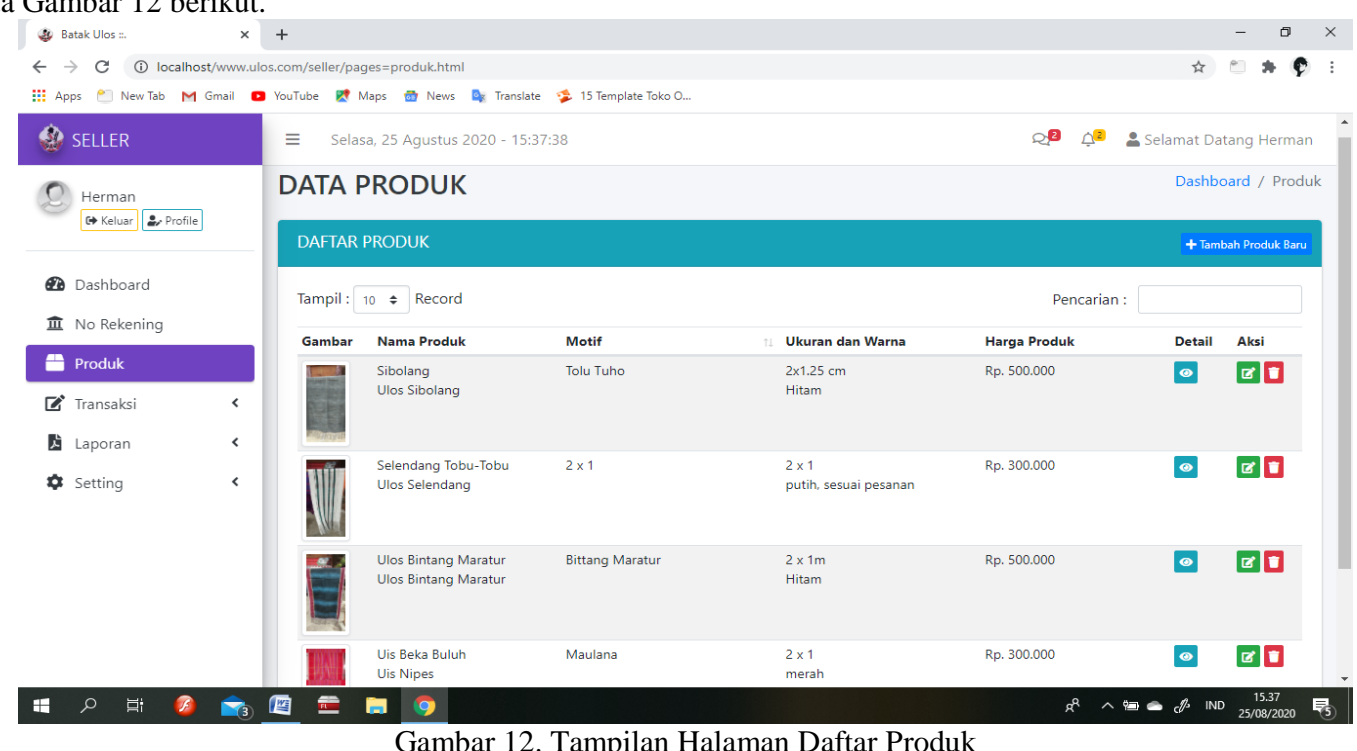

11. Tampilan Halaman Transaksi

Pada halaman ini akan ditampilkan informasi pesanan produk yang diterima dan produk yang dikirim. Adapun bentuk halaman transaksi dapat dilihat seperti pada Gambar 13 berikut.

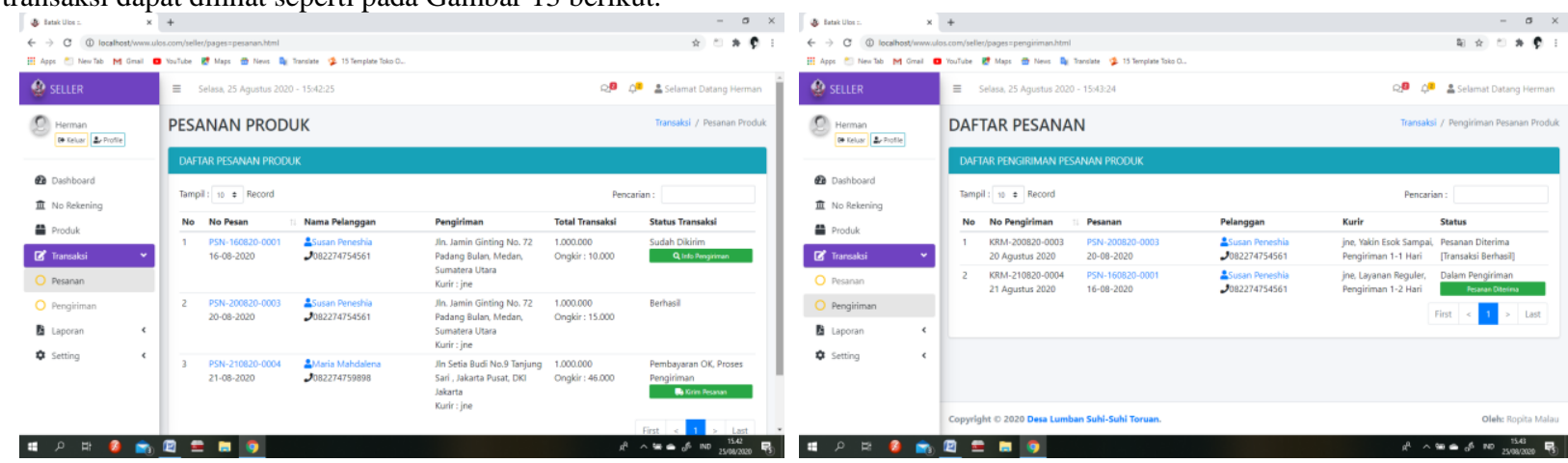

Gambar 13. Tampilan Halaman Transaksi

12. Tampilan Halaman Laporan

Tampilan halaman laporan menampilkan informasi dari daftar produk, pesanan yang diterima dan produk yang dikirm setiap melakukan pemesanan. Tampilan halaman laporan dapat dilihat seperti pada Gambar 14 berikut.

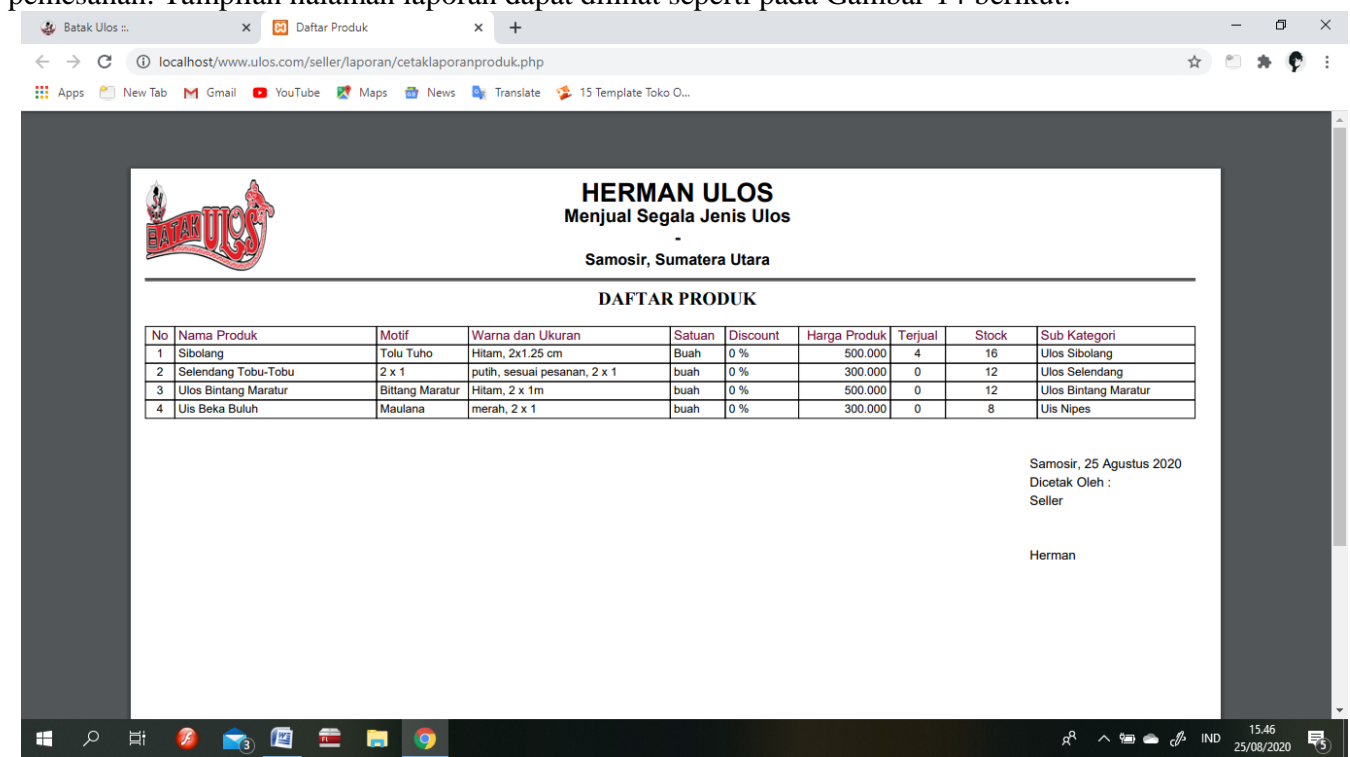

Gambar 14 Tampilan Halaman Laporan (daftar produk, laporan pesanan, laporan pengiriman)

Sistem Informasi Pemasaran dan Penjualan Hasil Tenun Ulos Desa Lumban Suhi-Suhi . 
13. Tampilan Halaman Pesan Masuk

Halaman pesan menampilkan informasi apabila pelanggan mengirimkan pesan kepada seller. Bentuk Tampilan halaman pesan masuk dapat dilihat seperti pada Gambar 15 berikut.

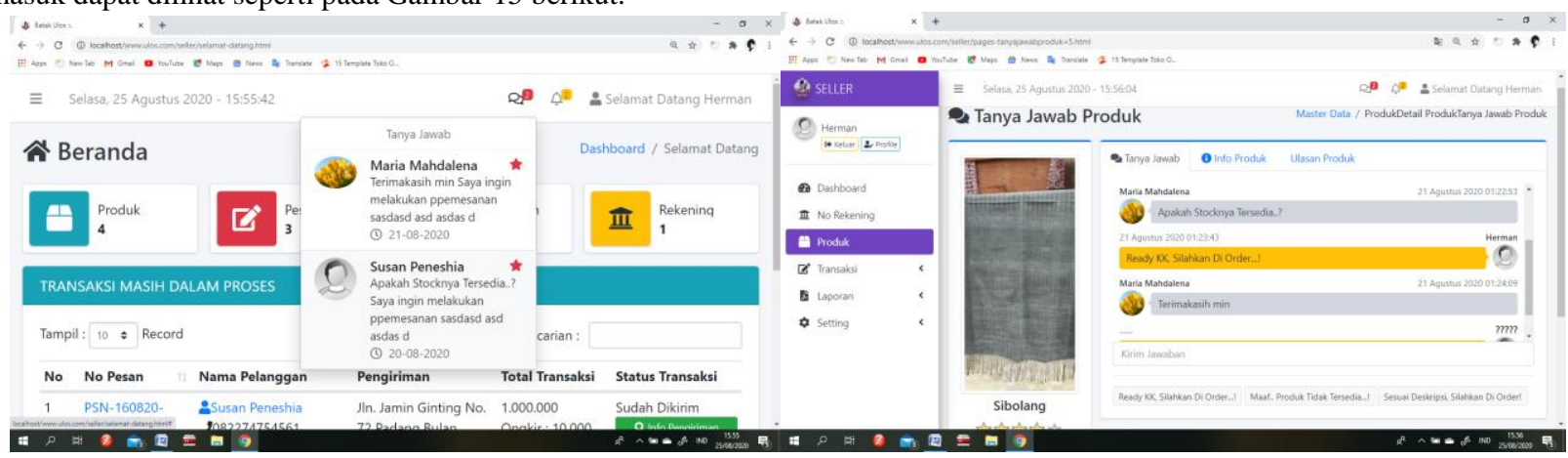

Gambar 15. Tampilan Halaman Pesan Masuk

14. Tampilan Halaman Utama Admin

Halaman utama adalah tampilan awal yang akan muncul pada saat administrator sukses melakukan login. Halaman utama memiliki banyak fitur yang dapat digunakan untuk menjalankan sistem, seperti menu utama yang terdiri dari sub menu atau link yang dapat digunakan untuk berpindah halaman, panduan pengguna yang dapat dijadikan acuan oleh administrator dalam menjalankan sistem. Tampilan halaman utama admin dapat dilihat pada Gambar 16 berikut.

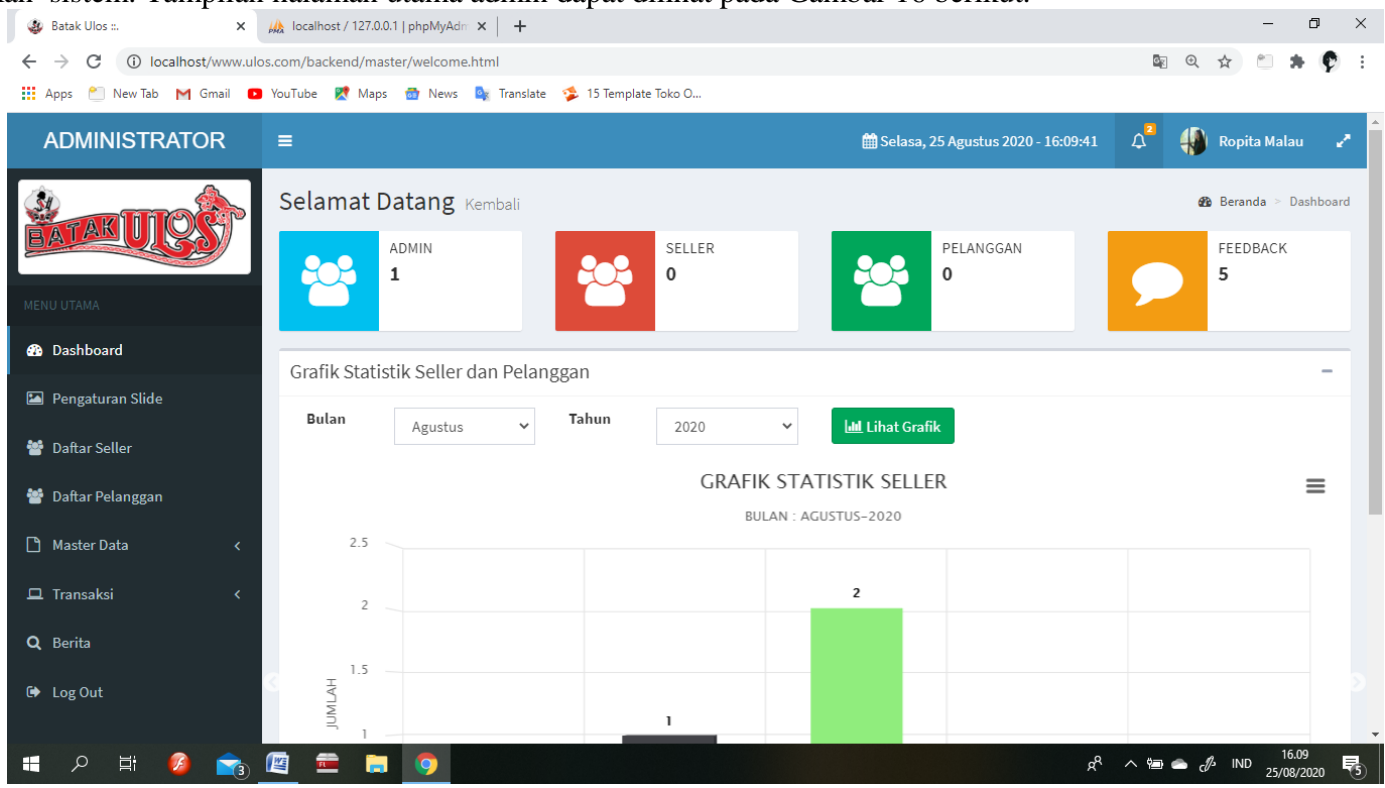

Gambar 16. Tampilan Halaman Utama Admin

15. Tampilan Antar Muka Daftar Seller

Antar muka daftar seller menampilkan seller ulos yang telah melakukan registrasi dan melakukan login. Tampilan antar muka datar seller dapat dilihat pada Gambar 16 berikut.

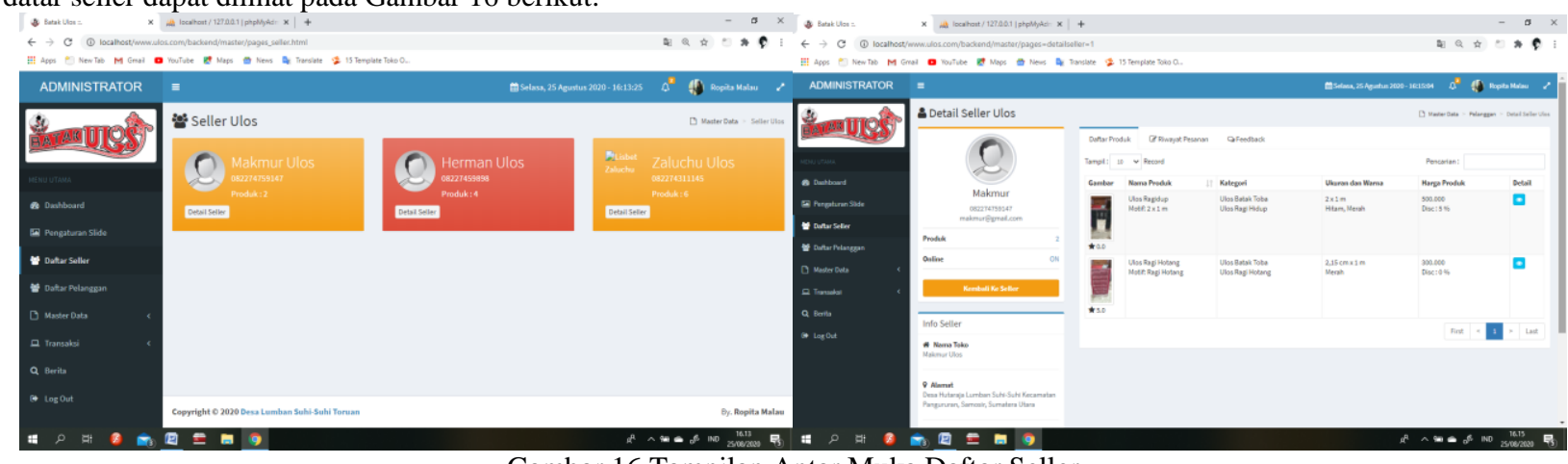

Gambar 16 Tampilan Antar Muka Daftar Seller

16. Tampilan Antar Muka Daftar Pelanggan

Antar muka daftar pelanggan menampilkan daftar pelanggan yang telah melakukan registrasi dan melakukan login.Tampilan antar muka jenis paketdapat dilihat pada Gambar 17 berikut. 


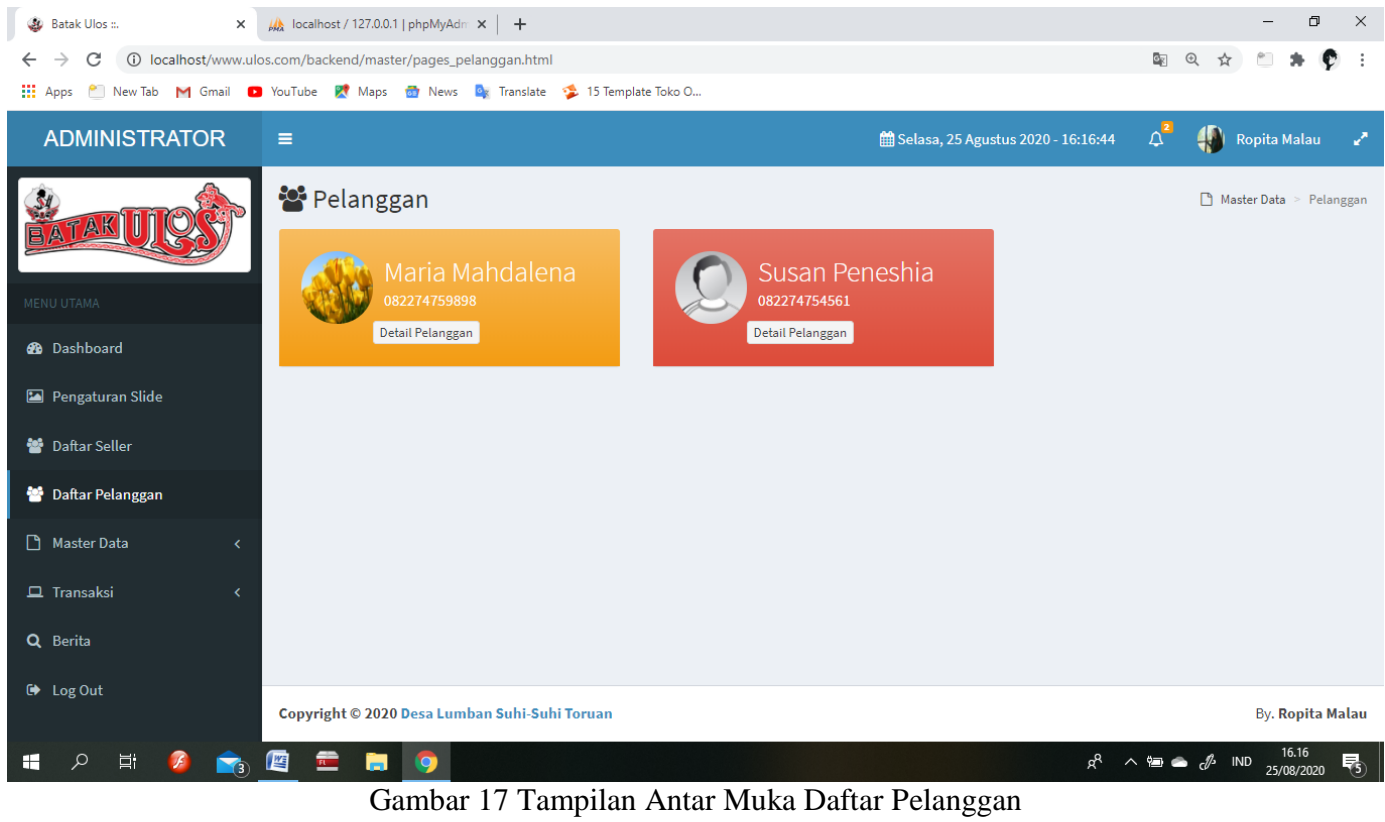

17. Tampilan Antar Muka Kategori Produk

Antar muka kategori produk berfungsi untuk menampilkan daftar jenis kategori produk yang dijual. Tampilan antar muka kategori produkdapat dilihat pada Gambar 18 berikut.

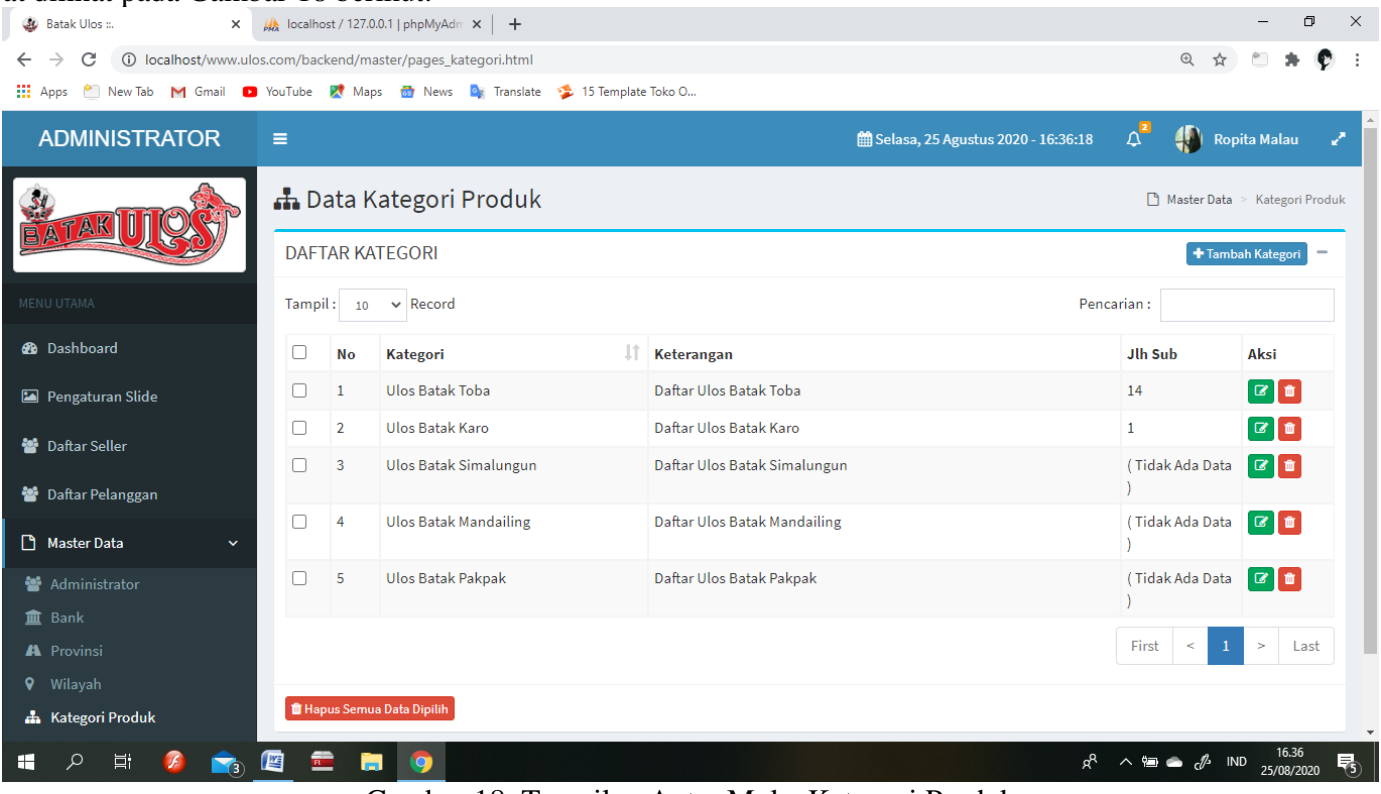

Gambar 18. Tampilan Antar Muka Kategori Produk

18. Tampilan Antar Muka Transaksi

Antar muka transaksi berfungsi untuk menampilkan transaksi yang telah dilakukan oleh selller. Tampilan antar muka transaksi dapat dilihat pada Gambar 19 berikut.

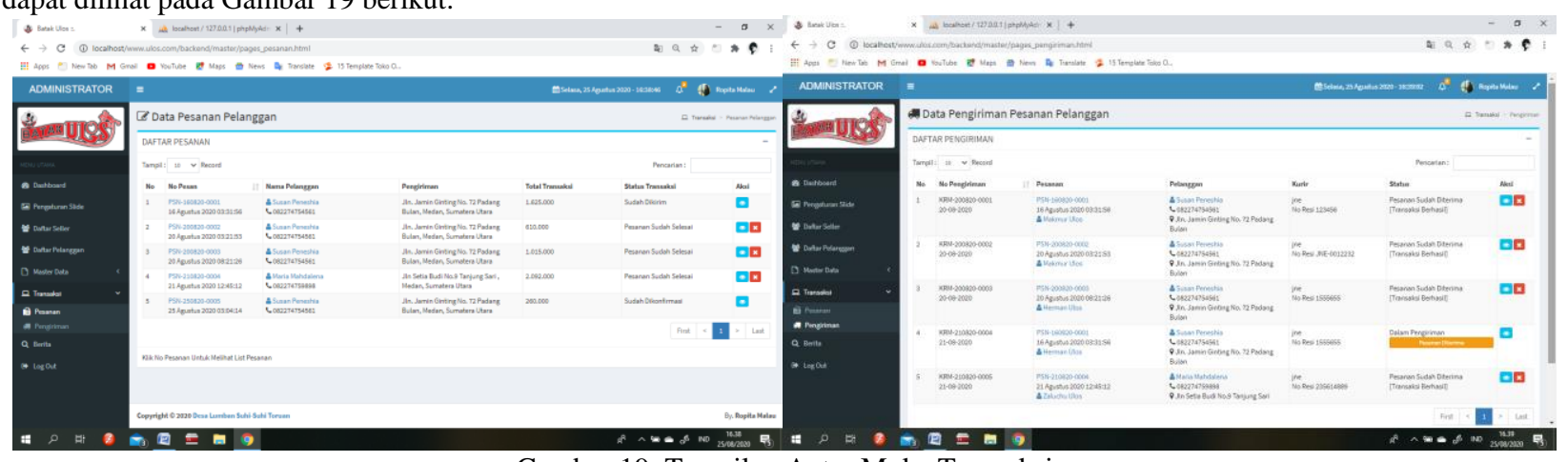

Gambar 19. Tampilan Antar Muka Transaksi

Sistem Informasi Pemasaran dan Penjualan Hasil Tenun Ulos Desa Lumban Suhi-Suhi . 
19. OutputLaporan Pesanan

Laporan pesanan berfungsi untuk menampilkan laporan pesanan ulos masing-masing seller. Tampilanlaporan pesanan dapat dilihat seperti pada Gambar 20 berikut.

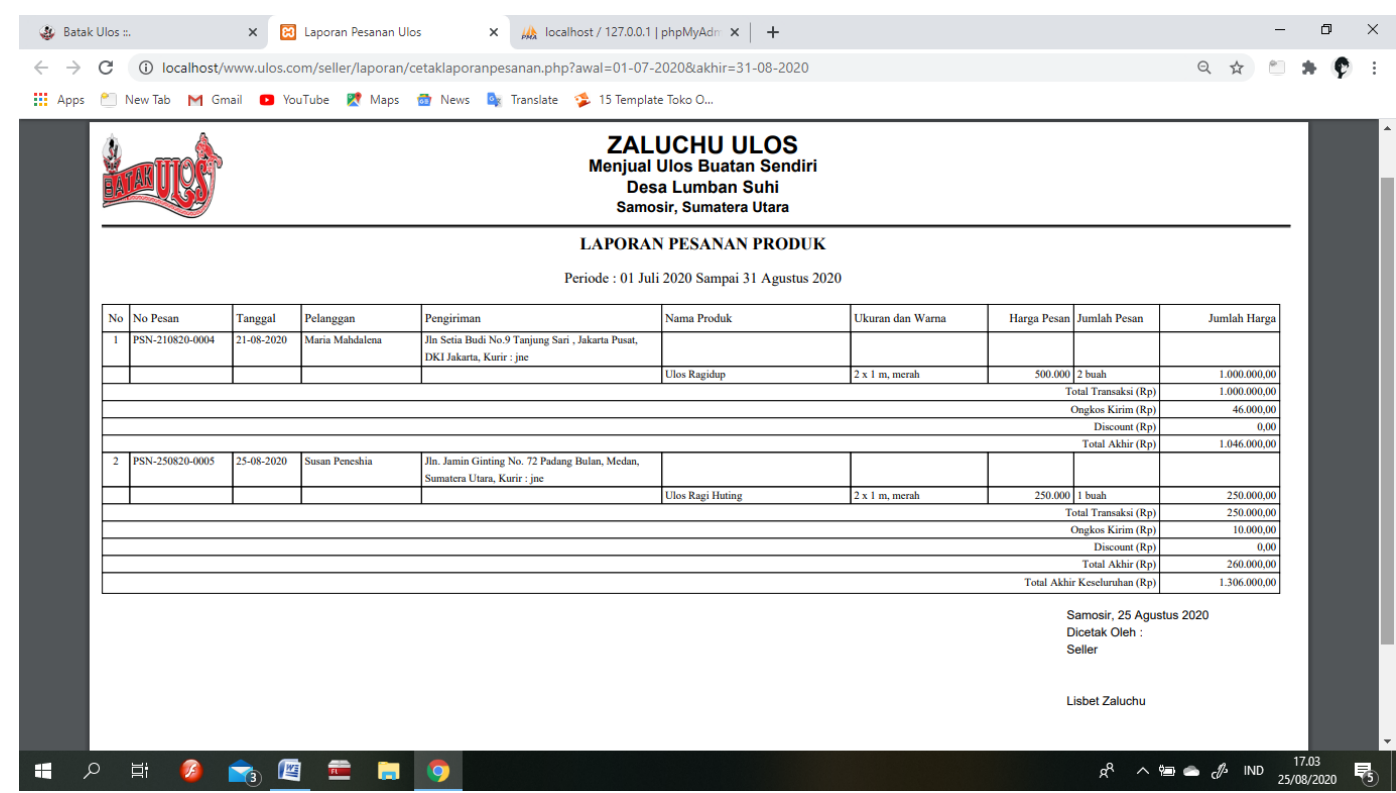

Gambar 20 Output Laporan Pesanan

\section{KESIMPULAN}

Berdasarkan hasil penelitian dan pembahasan yang telah dilakukan oleh peneliti dengan judul "Sistem Informasi Pemasaran dan Penjualan Hasil Tenun Ulos Desa Lumban Suhi-Suhi” maka dapat diambil kesimpulan sebagai berikut:

1. Dengan dibangunnya sistem informasi pemasaran dan penjualan hasil Ulos Desa Lumban Suhi-Suhi, dapat memberikan salah satu alternatif dan kemudahan dalam menjalankan pengembangan usaha Desa Tenun Ulos Desa Lumban Suhi-Suhi.

2. Sistem informasi pemasaran dan penjualan hasil Ulos Desa Lumban Suhi-Suhi sebagai media promosi Ulos kepada masyarakat.

3. Meningkatkan pelayanan kepada masyarakat serta mempermudah masyarakat memperoleh informasi.

4. Memberikan kemudahan kepada konsumen untuk melakukan pemesanan secara online.

\section{DAFTAR PUSTAKA}

[1] Candra Agustina, "Makna Dan Fungsi Ulos Dalam Adat Masyarakat Batak Toba Di Desa Talang Mandi Kecamatan Mandau Kabupaten Bengkalis," J. Ilmu Komun., vol. 3, no. 2, pp. 1-15, 2016.

[2] N. Harahap, “Analisis Bentuk Ragam Hias, Fungsi dan Makna Ulos Batak dalam Adat Masyarakat Mandailing Suamtra Utara," 2020.

[3] J. O. Sembiring and S. Pakpahan, "Sistem Informasi Pemesanan Dan Penjualan Barang pada Pintera Kreativ Berbasis Web,” MEANS (Media Inf. Anal. dan Sist., vol. 2, no. 2, pp. 146-152, Jan. 2018, doi: 10.17605/JMEANS.V2I2.152.

[4] M. Sinaga and E. P. Malau, "Sistem Informasi Penjualan pada Karo Rumah Mode di Simalingkar berbasis Web," MEANS (Media Inf. Anal. dan Sist., vol. 3, no. 1, pp. 49-56, 2018.

[5] R. Indonesia, "Presiden republik indonesia presiden republik indonesia," no. September, pp. 1-2, 2009, [Online]. Available: http://www2.pom.go.id/public/hukum_perundangan/pdf/Pengamanan rokok bagi kesehatan.pdf.

[6] P. D. Astuti, "Perancangan Sistem Informasi Penjualan," Semin. Ris. Unggulan Nas. Inform. dan Komput. FTI UNSA, vol. 2, no. Bisnis Inelijen, pp. 13-18, 2013.

[7] T. Sutabri, Konsep Sistem Informasi. Penerbit Andi, 2012.

[8] H. M. Jogiyanto, Analisis dan Desain (Sistem Informasi Pendekatan Terstruktur Teori dan Praktek Aplikasi Bisnis). Yogyakarta: Penerbit Andi, 2017.

[9] E. Kartini and P. Silitonga, "Sistem Informasi Wisata Kuliner di Kota Medan Berbasis Web," MEANS (Media Inf. Anal. dan Sist., vol. 2, no. 2, pp. 139-145, Jan. 2018, doi: 10.17605/JMEANS.V2I2.151.

[10] M. Ginting and S. Pakpahan, "Sistem Informasi Potensi Kependudukan Desa Sukajulu Berbasis Web," vol. 3, no. 2, pp. 147-151, 2018.

[11] Kabupaten Samosir, "Industri Kerajinan Kain Tenun Samosir Motif Ulos," WebsitePemkabSamosir, 2020. https://samosirkab.go.id/industri-kerajinan-kain-tenun-samosir-motif-ulos/ (accessed Nov. 10, 2020).

[12] Sugiyono, Metode Penelitian Kuantitatif, Kualitatif dan R\&D. Bandung: PT Alfabet, 2016.

[13] T. Limbong et al., Sistem Pendukung Keputusan: Metode \& Implementasi. Yayasan Kita Menulis, 2020. 